\section{Influensapandemien - fastlegens og legevaktens roller}

\section{Sammenliknet med andre pasientgrupper, oppsøkte pasienter i risiko- gruppene legevakt relativt oftere enn fastlege under influensapande- mien i 2009.}

I forkant av influensapandemien i 2009 var det stor usikkerhet om alvorlighetsgrad og antall syke som ville få behov for helsehjelp. Influensaepidemier fører generelt til stor søkning til primærhelsetjenesten, og de fleste pasientene ferdigbehandles der. Fornisk forløp og helsetjenestebruk hos pasienter under influensapandemien.

Mitt doktorgradsarbeid bygger på to ulike materialer: En spørreskjemaundersøkelse blant pasienter i Hordaland som i 2009 fikk influensadiagnose hos fastlegen $(\mathrm{N}=1324)$, hvorav 357 deltok, og to delstudier basert på data fra databasen Kontroll og utbetaling av helserefusjon (KUHR), med tall fra legevakt og fastlegepraksis. De fleste influensapasientene ble håndtert hos fastlegene, men legevakt hadde likevel mer enn en femdobling av influensakonsultasjoner i forhold til en normålet med avhandlingen var å beskrive kli- malsesong med influensa. Fastlegene benyttet fleksibiliteten sin og økte kapasiteten litt, mens legevakten behandlet langt færre andre pasienter og beholdt sin totalkapasitet. Influensapasienter tilhørende risikogruppene for alvorlig influensaforløp brukte legevakt i større grad enn fastlege sammenliknet med andre influenspasienter. Vi fant også at de som hadde hatt konsultasjon hos fastlegen før pandemien hadde lavere risiko for å oppsøke legevakt med influensaliknende sykdom under pandemien.

Funnene indikerer at fastlegene har tilstrekkelig kapasitet i en epidemisituasjon av relativt kort varighet og at legevakt har en viktig støttefunksjon.

\section{Kristian Anton Simonsen}

kristian.simonsen@uib.no

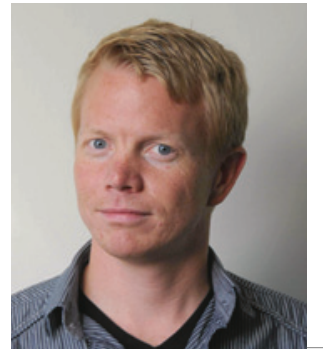
sen. Foto: Knut-Arne Wensaas
Kristian Anton Simon-

\section{Disputas}

Kristian Anton Simonsen disputerte for ph.d.graden ved Universitet i Bergen 25.3. 2015. Tittelen på avhandlingen er The 2009 influenza pandemic in primary care. Clinical manifestations, attitudes and utilisation of services.

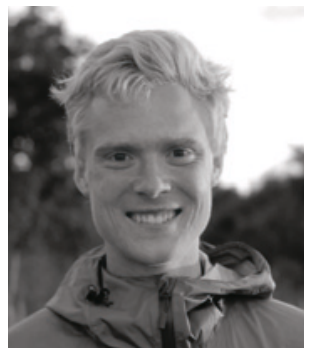

Mats Julius Stensrud. Foto: Louisa Linder trisk signal. Det har vært postulert at transmittere som aktiverer og hemmer aktiviteten i naboceller, frigjøres fra forskjellige nerveender.

Nerveceller i hippocampus er viktige for å bearbeide informasjon, og forstyrrelser i signaloverføringen kan føre til hjernesykdommer. Frigjøring av GABA og glutamat, som virker henholdsvis hemmende og aktiverende, er grunnleggende i signaltrafikken. I avhandlingen min viser jeg at en undergruppe av GABA-cellene i forsøksdyr inneholder de nødvendige molekylene for å frigjøre glutamat. Blant annet inneholder noen synaptiske vesikler både GABA-transportøren VGAT og glutamattransportøren
VGLUT3. Dermed kan hemmende og aktiverende signalstoffer slippes ut samtidig. Funnene utfordrer teorien om at hjernens nerveceller enten er hemmende eller aktiverende. Videre har jeg studert de dopamin erge nervebanene som går fra substantia nigra til striatum. Nerveender fra de nigrostriatale fibrene inneholder betydelige mengder GABA, selv om transportøren som vanligvis frakter GABA til vesikler er fraværende. GABA ser imidlertid ut til å bruke dopamins transportapparat for å få adgang til synaptiske vesikler.

Avhandlingen understreker at signaltrafikken i hjernen er mer kompleks enn tidligere antatt. Funnene kan ha betydning for forståelsen av epilepsi og Parkinsons sykdom.

Mats Julius Stensrud m.j.stensrud@medisin.uio.no 